\title{
Faits techniques et valeurs sociales : quelques directions de recherche
}

\section{Pierre Bonte}

\section{(2) OpenEdition \\ 1 Journals}

Édition électronique

URL : https://journals.openedition.org/tc/951

DOI : $10.4000 /$ tc. 951

ISSN : 1952-420X

Éditeur

Éditions de l'EHESS

\section{Édition imprimée}

Date de publication : 1 juin 1985

ISSN : 0248-6016

\section{Référence électronique}

Pierre Bonte, «Faits techniques et valeurs sociales : quelques directions de recherche », Techniques \& Culture [En ligne], 5 | 1985, mis en ligne le 25 janvier 2006, consulté le 29 septembre 2022. URL : http:// journals.openedition.org/tc/951; DOI : https://doi.org/10.4000/tc.951

Ce document a été généré automatiquement le 29 septembre 2022.

Tous droits réservés 
Faits techniques et valeurs sociales : quelques directions de recherche

Pierre Bonte 